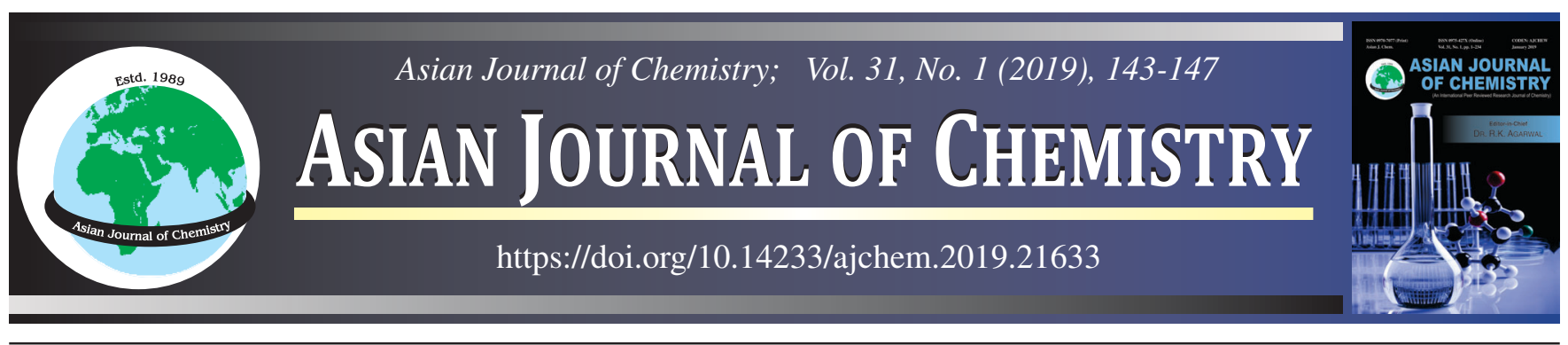

\title{
Phytochemical Analysis and Antibacterial Activity of Extracts from Palestinian Aleppo Pine Seeds, Bark and Cones
}

\author{
Hatim Salim ${ }^{1}$, Waleed H. Rimawi ${ }^{1, *}$, Safa Shaheen ${ }^{1}$ and Arwa Muahed ${ }^{2}$
}

${ }^{1}$ Department of Applied Chemistry, Palestine Polytechnic University, P.O. Box 198, Hebron, Palestinian Territories

${ }^{2}$ Department of Applied Biology, Palestine Polytechnic University, P.O. Box 198, Hebron, Palestinian Territories

*Corresponding author: Fax: +972 2 2233050; Tel: +972 599385347; E-mail: whrimawi@ ppu.edu

Received: 4 August 2018;

Accepted: 31 August 2018;

Published online: 30 November 2018;

AJC-19173

| Pinus halepensis (Aleppo pine) is one of the most common trees that are known for their medicinal and economic importance in the Mediterranean region. This work aimed to determine the total phenolic, flavonoid and lipid contents, as well as to study the antioxidant and antibacterial activities of extracts obtained from different parts (cones, bark and seeds) of Pinus halepensis trees cultivated in Palestine. Two extraction techniques (maceration and Soxhlet) using thee different solvents (ethanol, $80 \%$ methanol and hexane) were applied. The results showed that among all extracts, methanolic extract of cones had the highest total phenolic content (431.38 mg equivalent gallic acid/g extract) and the best total flavonoid content (193.25 mg catechin equivalent/g extract) and demonstrated the highest antioxidant activity with $\mathrm{EC}_{50}$ of $1.48 \mu \mathrm{g} / \mathrm{mL}$. The highest total lipid content using hexane as extraction solvent was found for the extract from seeds (30.1\%). The antibacterial activity of the extracts was studied using agar dilution method against Shigella, Escherichia coli and Staphylococcus aureus. Solutions of the obtained extracts with the concentration range of $10^{-5}$ to $10^{-2} \mathrm{~g}$ extract $/ \mathrm{mL}$ in $20 \%$ aqueous DMSO exhibited 15-80 \%, 20-80\% and 20-95 \% bacterial inhibition of Shigella, Escherichia coli and Staphylococcus aureus, respectively. (

Keywords: Aleppo pine, Phytochemical analysis, Antibacterial activity.

\section{INTRODUCTION}

Throughout the ages humans have relied on nature to cater for their basic needs, such as medicines for the treatment of a wide spectrum of diseases. Medicinal plants, in particular, have formed the basis of sophisticated traditional medicine systems. These plants are considered as a rich source of ingredients which can be used in drug development and synthesis [1-3].

The pine tree (Pinus) is one of the most widely distributed medicinal plants in the Northern hemisphere, encompassing nearly 100 species. It is tall, evergreen, monoecious tree. Some of its species grows well in acid soils, others in calcareous soils, but most of them require good soil drainage, preferring sandy soils [4,5]. Pines are important components of flora in Mediterranean basin that has an unusual geographical and topographical diversity [6]. In addition to their health benefits, almost all parts of pine tree, specially seeds, have high nutritional value and thus are included as ingredients in a variety of traditional dishes [7].
Aleppo pine (Pinus halepensis) is the most common species of pine in the Mediterranean basin, particularly in the western part. It is found in all countries around the Mediterranean, except Libya and Egypt. It is also being planted in warm temperate, semiarid areas of Argentina, México, the Soviet Union, South Africa and Australia [8,9]. In Palestine, the Aleppo pine, along with Pinus brutia, has been planted extensively. They are widely distributed and used for recreational purposes.

In the last two decades an enormous number of studies were performed in different countries of Mediterranean basin on extracts and essential oils isolated from different parts (seeds, cones and bark) of Aleppo pine. These works focused on the health effects $[10,11]$, chemical composition, particularly the content of polyphenpls, fatty acids, amino acids, minerals, in addition to antioxidant, antibacterial and antifungal activities [12-22].

It can be noted from the results of the previous studies that there are significant differences in the composition and

This is an open access journal, and articles are distributed under the terms of the Creative Commons Attribution-NonCommercial 4.0 International (CC BY-NC 4.0) License, which allows others to copy and redistribute the material in any medium or format, remix, transform, and build upon the material, as long as appropriate credit is given and the new creations are licensed under the identical terms. 
activities of essential oil and extracts of Aleppo pine depending on the part of plant and the region were the plant was grown. In addition, most of these works are about Aleppo pine grown in Europe and North Africa (northern and western regions of the Mediterranean), but studies on the plant grown in the south eastern region of the Mediterranean are scarce and none of these studies was related to the pine trees in Palestine. Therefore, present study aims at investigating extracts from different parts of the Pinus halepensis trees that grow in Palestine, especially the area of Hebron, for their total phenolic content, antioxidant capacity, total flavonoid content, total lipids and compare them with those of trees cultivated in other parts of the world.

Furthermore, the results of some studies revealed that the essential oil of seeds of Aleppo pine showed moderate activity against all the bacterial strains except Pseudomonas aeruginosa and Escherichia coli that were found to be very resistant [23]. Therefore, in present work we also studied the growth inhibiting activity of extracts from Aleppo pine against Shigella, Escherichia coli and Staphylococcus aureus.

\section{EXPERIMENTAL}

Aleppo pine seeds, bark and cones were collected from Alsamo'-Hebron $\left(31.400792^{\circ} \mathrm{N} 35.067075^{\circ} \mathrm{E}\right)$ in Palestine. Seeds were directly stored at $15^{\circ} \mathrm{C}$ for a maximum of 3 days and then cleaned manually to remove foreign matter. Cones and bark were dried in oven at $170{ }^{\circ} \mathrm{C}$. Then samples of each part were separately milled in a heavy-duty grinder for 4 min to obtain powder which was stored at $-20{ }^{\circ} \mathrm{C}$ until subsequent analysis.

Solvent extraction: The fine powdered seeds, bark and cones $(50 \mathrm{~g})$ were extracted separately using $250 \mathrm{~mL}$ of each of $80 \%$ methanol, ethanol and hexane by maceration for $3 \mathrm{~h}$ under intensive stirring in a dark at ambient temperature. Then the solvent was removed under vacuum at $40^{\circ} \mathrm{C}$ and the obtained dry extract was stored at $-20^{\circ} \mathrm{C}$.

Soxhlet extraction: The same weights ( $50 \mathrm{~g}$ ) of powdered seeds, bark and cones was extracted on Soxhlet extractor using the same solvents for $6 \mathrm{~h}$ at ambient temperature.

Determination of total phenolic content (TPC): Total phenolic content was determined using Folin reagent according to the procedure described in literature [24]. $10 \mathrm{mg}$ of each extract sample was dissolved in $10 \mathrm{~mL}$ of $80 \%$ methanol to prepare extract solutions with the concentration of $1 \mathrm{mg}$ extract/ mL. $0.5 \mathrm{~mL}$ of each solution was thoroughly mixed with 2.5 $\mathrm{mL}$ of Folin reagent and $2.0 \mathrm{~mL} 7.5 \%$ sodium carbonate solution and left for $40 \mathrm{~min}$. Then the absorbance was measured at $760 \mathrm{~nm}$. Standard solutions of gallic acid were used to construct calibration curve that was used for the calculation of Total phenolic content which was expressed as mg gallic acid equivalent per gram of dry extract.

Determination of total flavonoid content (TFC): The (TFC) was determined using $\mathrm{AlCl}_{3}$ colorimetric method [25]. $5.0 \mathrm{mg}$ of each extract was dissolved in $10 \mathrm{~mL}$ methanol. Then to $1 \mathrm{~mL}$ of each solution $4 \mathrm{~mL}$ of distilled water, $0.3 \mathrm{~mL}$ of 5 $\% \mathrm{NaNO}_{2}$ solution, $0.6 \mathrm{~mL}$ of $10 \% \mathrm{AlCl}_{3}$ solution and $2 \mathrm{~mL}$ of $\mathrm{NaOH}(1 \mathrm{M})$ were added and allowed to stand for $6 \mathrm{~min}$. The absorbance was then measured at $510 \mathrm{~nm}$ against water as blank. Standard solutions of catechin were used to construct calibration curve that was used for the calculation of total flavonoid content as milligram of catechin equivalents per gram of dry extract (mg CE/g dried extract).

Determination of DPPH free radical scavenging activity: The radical scavenging activity of the methanolic and ethanolic extracts of the three parts against 2,2'-diphenyl-1-picrylhydrazyl (DPPH) radicals was measured as described in the work [26]. The extract of seeds was dissolved in methanol to get different concentrations $(80,60,40,20$ and $10 \mu \mathrm{g} / \mathrm{mL})$. For extracts of cones and bark $(2,4,6,8,10 \mu \mathrm{g} / \mathrm{mL})$ solutions were used. Then an aliquot $(4 \mathrm{~mL})$ of each solution was added to $1 \mathrm{~mL}$ of freshly prepared (DPPH) solution $(0.2 \mathrm{mM})$ and was allowed to stand for $30 \mathrm{~min}$ at ambient temperature. The absorbance was measured at $517 \mathrm{~nm}$. The results were expressed as radical scavenging percentage of the DPPH according to the formula:

$$
\text { DPPH scavenging effect }(\%)=\frac{\mathrm{A}_{\text {blank }}-\mathrm{A}_{\text {sample }}}{\mathrm{A}_{\text {blank }}} \times 100
$$

where $\mathrm{A}_{\text {blank }}$ is the absorbance of the blank control solution and $\mathrm{A}_{\text {sample }}$ is the absorbance in the presence of plant extract. The extract concentration resulting in $50 \%$ radical inhibition activity $\left(\mathrm{EC}_{50}\right)$ expressed as $\mathrm{mg}$ extract $/ \mathrm{mL}$ was determined from the graph of the free radical scavenging activity (\%) versus extract concentration.

Determination of total lipids: Lipids were extracted by maceration of fine powdered seeds, bark and cones for $3 \mathrm{~h}$ (three times for each) using hexane at ambient temperature. The solvent was evaporated under vacuum at $40^{\circ} \mathrm{C}$ till constant weight. The obtained lipid material was weighed and the total lipids was calculated as a percentage from the dry plant material. The oil also was extracted from a ground sample of Aleppo pine seeds and cones powder in a Soxhlet extractor for $8 \mathrm{~h}$ using hexane as a solvent at $45{ }^{\circ} \mathrm{C}$.

Determination of antibacterial activity: The antibacterial activity of the extracts against Staphylococcus aureus, Escherichia coli and Shigella was screened using the agar dilution method [27]. $100 \mathrm{mg}$ of each extract was dissolved in $10 \mathrm{~mL}$ of aqueous (20\%) DMSO. Using serial dilution, solutions with the concentrations of $10^{-2}, 10^{-3}, 10^{-4}$ and $10^{-5} \mathrm{~g}$ extract/ $\mathrm{mL}$ were prepared. These solutions were stored at $40^{\circ} \mathrm{C}$. Then $100 \mu \mathrm{L}$ of each extract solution was spread on plate and left to dry. Then $1 \mu \mathrm{L}$ of bacteria was spread on each plate using $1 \mu \mathrm{L}$ inoculation loop. The plates were incubated aerobically at $37^{\circ} \mathrm{C}$ for $24 \mathrm{~h}$. The number of colonies on each plate was counted manually. A plate containing aqueous (20\%) DMSO was used as a positive control to calculate the percent inhibition of bacteria.

\section{RESULTS AND DISCUSSION}

Extraction: Three solvents were used for the extraction of the dried powdered plant material. Two of them (ethanol and $80 \%$ methanol) are highly polar and the third is nonpolar (hexane). In addition, two types of extraction procedures (maceration and Soxhlet) were applied. The percentage yield of solid extract was found as (g extract/100 g dried plant material) and shown in Table-1. It can be seen that the yield 
TABLE-1

PHYTOCHEMICAL VALUES OF DIFFERENT PARTS OF Pinus halepinsis

\begin{tabular}{|c|c|c|c|c|c|c|c|c|}
\hline \multirow{3}{*}{ Extract } & \multicolumn{2}{|c|}{ Extracts $(\%)$} & \multicolumn{2}{|c|}{ Total phenolic content } & \multicolumn{2}{|c|}{ Total flavonoid content } & \multicolumn{2}{|c|}{$\begin{array}{c}\text { DPPH radical } \\
\text { scavenging activity }\end{array}$} \\
\hline & \multicolumn{2}{|c|}{$\begin{array}{c}\mathrm{g} \text { Extract } / 100 \mathrm{~g} \text { plant } \\
\text { material }\end{array}$} & \multicolumn{2}{|c|}{$\begin{array}{c}\text { TPC (mg EGA/g dried } \\
\text { extract) }\end{array}$} & \multicolumn{2}{|c|}{ TFC (mg CE/g dried extract) } & \multicolumn{2}{|c|}{$\mathrm{EC}_{50}(\mathrm{mg} / \mathrm{mL})$} \\
\hline & Maceration & Soxhlet & Maceration & Soxhlet & Maceration & Soxhlet & Maceration & Soxhlet \\
\hline Ethanolic PHS & 22.4 & 25.9 & 5.03 & 4.52 & 24.92 & 16.86 & 0.0461 & 0.2140 \\
\hline Methanolic PHS & 5.9 & 7.6 & 47.96 & 30.38 & 17.14 & 8.25 & 0.1270 & 0.4380 \\
\hline Hexanoic PHS & 27.5 & 30.1 & 4.52 & 4.35 & 43.25 & 38.81 & 0.2350 & 0.3340 \\
\hline Ethanolic PHC & 14.9 & 15.5 & 414.17 & 407.79 & 179.64 & 111.86 & 0.0014 & 0.0032 \\
\hline Methanolic PHC & 10.6 & 12.9 & 431.38 & 412.79 & 193.25 & 186.58 & 0.0015 & 0.0015 \\
\hline Hexanoic PHC & 3.8 & 6.3 & 64.86 & 57.45 & 76.31 & 46.03 & 0.1890 & 0.9100 \\
\hline Ethanolic PHB & 7.0 & 13.3 & 397.79 & 253.65 & 71.02 & 64.92 & 0.0029 & 0.0062 \\
\hline Methanolic PHB & 22.1 & 23.8 & 369.00 & 314.34 & 126.58 & 87.97 & 0.0031 & 0.0047 \\
\hline Hexanoic PHB & 3.0 & 6.4 & 17.62 & 12.10 & 12.69 & 12.14 & 0.0960 & 0.1640 \\
\hline
\end{tabular}

varies from 3.8 to $30 \%$ with seeds hexanoic extract having the highest extract percent (30.1\%). In general, Soxhlet extractions gave results better than those by maceration. The extract yield from seeds was the highest using hexane while that from cones and bark was the better when ethanol and methanol were used, respectively. This can be explained by the relatively high content of essential oil in seeds which is more efficiently extracted using non-polar hexane.

Determination of total phenolic content (TPC): The TPC of Pinus halepinsis extracts was determined by FolinCiocalteau assay using gallic acid as a standard phenolic compound. The results for determining TPC in all extracts are presented in Table-1. The values of TPC in obtained extracts are found to be in the range of 4.5-432, while the highest TPC was determined in cones methanolic extract 431.38 , followed by bark extracts, while seeds extracts had the lowest values.

In addition, methanolic extracts gave a higher TPC than ethanolic and hexanoicones. For ethanolic extracts cones also gave the highest TPC, followed by the bark extract, while seeds had the lowest TPC among all ethanolic extracts. For all extracts, hexanoic extracts gave the lowest values of TPC.

The value of TPC for hexanoic seeds extract $(\mathrm{TPC}=4.52)$ in this study was significantly higher than that reported for the same species in literature [28].

Determination of total flavonoid content (TFC): Flavonoids, the most common polyphenolic compounds have antioxidant activity and are ubiquitously found in plants. The results of determining the TFC for extracts obtained from different parts of Palestinian Aleppo pine tree using three solvents are showed in Table-1. The results were calculated using the regression equation of calibration curve $(y=0.0038 \mathrm{x}-0.0045$, $\left.\mathrm{R}^{2}=0.9969\right)$ and expressed as Catechin equivalent. From Table-1, we can see that TFC content varies depending on plant part and solvent.

The values of TFC were found to be in the range of 8-193. The highest one was determined form ethanolic extract of cones (193.25). Methanolic extracts gave a higher TFC than those of ethanolic extracts for all parts of the plant which emphasizes the results of TPC.

It should be mentioned that the value of TFC for methanolic extracts of seeds and cones extracts (TFC $=17.14,193.25$, respectively) in the current work were much higher than those reported for the same species in literature [13] in which the methanolic extracts of seeds and cones had TFC equal 0.35 and 3.26, respectively. This can be attributed to the differences in climate, soil composition and other conditions in the countries were the plant was grown [22].

Determination of DPPH free radical scavenging activity: The antioxidant activity of the all extracts was determined from the reduction in absorbance of the DPPH radicals at $517 \mathrm{~nm}$, resulted from the scavenging of these radicals by the active compounds contained in extracts. The values of effective extract concentration having $50 \%$ radical inhibition activity $\left(\mathrm{EC}_{50}\right)$ were calculated from the curves showing the dependence of inhibition activity on the extract concentration of each extract and presented in Table-1.

According to Table-1, methanolic extracts of all parts of plant exhibited better antioxidant activity than extracts obtained using ethanol and hexane as extraction solvent, what completely agrees with the results for TPC and TFC.

Furthermore, the cones methanolic extracts was the best antioxidant followed by bark and seeds extracts.

The DPPH radicals inhibition activity of cones and seeds methanolic extracts $\left(\mathrm{EC}_{50}=0.00148 \mathrm{mg} / \mathrm{mL}\right.$ and $0.127 \mathrm{mg} / \mathrm{mL}$, respectively) was significantly better than that for extracts from the same parts obtained in the in the work [13] in which $\mathrm{EC}_{50}$ was $0.474 \mathrm{mg} / \mathrm{mL}$ for cones and $2.323 \mathrm{mg} / \mathrm{mL}$ for seeds extracts.

From these results and those concerning TPC and TFC of extracts from Pinus halepensis seeds, bark and cones obtained in this work for Palestinian plant and comparing them with those in other studies in other countries, it is clear that Palestinian plant exhibits better results concerning the studied parameters than the same species from other parts of the world. Furthermore, similar tendency was noted in previous work [27], in which the same parameters for extracts from Palestinian Inula Viscosaa were significantly higher than those for the same plant cultivated in Tunisia [29]. These results enable to make an assumption about the distinguished properties of these and maybe other medicinal plants grown in Palestinian Territories.

Determination of total lipid content: Lipids were extracted from fine powdered parts of plants by both maceration and Soxhlet techniques using hexane at ambient temperature. The results are expressed as mass percent of total lipids from the dry material and represented in Table- 2 . 
TABLE-3

INHIBITION PERCENT OF Shigella, Escherichia coli AND Staphylococcus aureus BY EXTRACTS OF Pinus halepinsis

\begin{tabular}{|c|c|c|c|c|c|c|c|c|c|c|c|c|}
\hline \multirow{3}{*}{ Extract } & \multicolumn{12}{|c|}{ Inhibition (\%) } \\
\hline & \multicolumn{4}{|c|}{ Shigella } & \multicolumn{4}{|c|}{ Escherichia coli } & \multicolumn{4}{|c|}{ Staphylococcus aureus } \\
\hline & $\begin{array}{c}10^{-2} \\
\mathrm{~g} / \mathrm{mL}\end{array}$ & $\begin{array}{c}10^{-3} \\
\mathrm{~g} / \mathrm{mL}\end{array}$ & $\begin{array}{c}10^{-4} \\
\mathrm{~g} / \mathrm{mL}\end{array}$ & $\begin{array}{c}10^{-5} \\
\mathrm{~g} / \mathrm{mL}\end{array}$ & $\begin{array}{c}10^{-2} \\
\mathrm{~g} / \mathrm{mL}\end{array}$ & $\begin{array}{c}10^{-3} \\
\mathrm{~g} / \mathrm{mL}\end{array}$ & $\begin{array}{c}10^{-4} \\
\mathrm{~g} / \mathrm{mL}\end{array}$ & $\begin{array}{c}10^{-5} \\
\mathrm{~g} / \mathrm{mL}\end{array}$ & $\begin{array}{c}10^{-2} \\
\mathrm{~g} / \mathrm{mL}\end{array}$ & $\begin{array}{c}10^{-3} \\
\mathrm{~g} / \mathrm{mL}\end{array}$ & $\begin{array}{c}10^{-4} \\
\mathrm{~g} / \mathrm{mL}\end{array}$ & $\begin{array}{c}10^{-5} \\
\mathrm{~g} / \mathrm{mL}\end{array}$ \\
\hline Ethanolic extract of seeds & 48.2 & 35.1 & 29.9 & 25.3 & 67.8 & 52.0 & 44.8 & 20.9 & 95.1 & 90.2 & 85.1 & 74.7 \\
\hline Methanolic extract of seeds & 30.1 & 24.9 & 20.3 & 15.2 & 54.2 & 53.1 & 49.1 & 39.8 & 70.2 & 64.9 & 59.8 & 44.9 \\
\hline Ethanolic extract of cones & 74.9 & 64.7 & 49.8 & 34.8 & 63.5 & 58.7 & 57.4 & 47.9 & 80.4 & 72.1 & 60.1 & 50.3 \\
\hline Methanolic extract of cones & 79.8 & 70.2 & 35.3 & 24.9 & 68.9 & 63.3 & 56.6 & 49.3 & 74.8 & 60.3 & 54.9 & 50.2 \\
\hline Ethanolic extract of bark & 75.4 & 30.3 & 24.7 & 19.8 & 55.8 & 52.5 & 50.7 & 41.6 & 40.3 & 34.8 & 30.4 & 24.6 \\
\hline Methanolic extract of bark & 64.8 & 60.1 & 44.8 & 35.2 & 79.9 & 63.8 & 45.6 & 36.7 & 42.7 & 39.7 & 24.8 & 20.4 \\
\hline
\end{tabular}

TABLE-2

TOTAL LIPIDS (\%) OF DIFFERENT PARTS OF Pinus halepinsis

\begin{tabular}{lcc}
\hline \multirow{2}{*}{ Extract } & \multicolumn{2}{c}{ Total lipids (\%) } \\
\cline { 2 - 3 } & Maceration & Soxhlet \\
\hline Pinus halepinsis seeds & 27.5 & 30.1 \\
Pinus halepinsis cones & 3.8 & 6.3 \\
Pinus halepinsis bark & 3.1 & 6.4 \\
\hline
\end{tabular}

Seeds had the highest content of lipids followed by bark and cones. The value of total lipid in seeds $(30.1 \%)$ was lower than those for the same species obtained in literature [28] which had a value of $43.3 \%$. The difference in lipid content may due to differences in growing conditions of the plant and collecting season may affect the lipid content.

Antibacterial activity: In recent years, there has been a growing interest in developing new antimicrobial agents from various sources to combat microbial resistance. Several bioassays such as disk-diffusion, well diffusion and broth or agar dilution methods are well known and commonly used as antimicrobial activity screening and evaluating methods [30]. In this work agar dilution method was used for screening the antibacterial activity of the obtained extracts against Shigella, Staphylococcus aureus and Escherichia coli. The results are presented in Table-3.

Table-3 shows the inhibition percent using extracts solutions in $20 \%$ DMSO obtained from different parts of plant with different concentrations.

For Shigella, the inhibition effect of extracts was in the range of 15-80\%. Methanolic extracts of cones shows higher inhibition with higher concentration followed by bark ethanolic and methanolic extracts. While the inhibition of E. coli bacteria was in the range of 20-80\%. Methanolic extract of bark shows the higher inhibition followed by cones methanolic and seed ethanolic extracts. According to Staphylococcus aureus, the inhibition was in the range of 20-95\%. Ethanolic extract of seeds shows the higher inhibition followed by cones ethanolic and methanolic extracts. The results showed that in the studied concentration range, a strong dependence of inhibition activity on extract concentration exists. Using extracts with the concentration of $10^{-2} \mathrm{~g} / \mathrm{mL}$ can be recommended, since it resulted in 80-95\% inhibition of studied bacteria.

\section{Conclusion}

The results of the present work showed strong dependence of TPC, TFC, lipid content and the antioxidant activity of the extracts from Pinus halepensis on the plant part and extraction solvent. The extracts obtained from Palestinian Pinus halepensis collected in January from Palestine/Hebron have significantly higher levels of TPC, TFC and antioxidant activities than those obtained from the same species cultivated in other countries. Therefore, they can serve as potential source of valuable natural antioxidants. In addition, the extracts obtained exhibited a good antibacterial activity (80-95\% inhibition) against Shigella, E. coli $\mathrm{DH} 5 \alpha$ and Staphylococcus aureus.

\section{CONFLICT OF INTEREST}

The authors declare that there is no conflict of interests regarding the publication of this article.

\section{REFERENCES}

1. C. Veeresham, J. Adv. Pharm. Technol. Res., 3, 200 (2012); https://doi.org/10.4103\%2F2231-4040.104709.

2. J.W. Bennett, Can. J. Bot., 73(S1), 917 (1995); https://doi.org/10.1139/b95-339.

3. J.D. Phillipson, Phytochemistry, 56, 237 (2001); https://doi.org/10.1016/S0031-9422(00)00456-8.

4. J.N. Owens, and H.G. Lund, Forests and Forest Plants, Encyclopedia of Life Support Systems, vol. 1 (2009).

5. G.A. Petrides, A Field Guide to Western Trees: Western United States and Canada, Houghton Mifflin Company: Boston, New York, edn 1, vol. 44, Chap. I (1998).

6. D.M. Richardson, Ecology and Biogeography of Pinus, Cambridge University Press: Cambridge, Chap. 3, pp. 95-145 (2000).

7. G. P. Savage, QualitasP lantarum, 5, 75 (2001); https://doi.org/10.1023/A:1008175606698.

8. B. Slippers, G. Fourie, P.W. Crous, T.A. Coutinho, B.D. Wingfield, A.J. Carnegie and M.J. Wingfield, Stud. Mycol., 50, 343 (2004).

9. M. Vidakovic, Conifers: Morphology and Variation, Grafièki Zavod Hrvatske, Zagreb (1991).

10. N.G. Passalacqua, P.M. Guarrera and G. De Fine, Fitoterapia, 78, 52 (2007); https://doi.org/10.1016/j.fitote.2006.07.005.

11. I. Süntar, I. Tumen, O. Ustün, H. Keles and E.K. Akkol, J. Ethnopharmacol., 139, 533 (2012);

https://doi.org/10.1016/j.jep.2011.11.045.

12. T. Dob, T. Berramdan and C. Chelgoum, Comp. Rend. Chim., 8, 1939 (2005); https://doi.org/10.1016/j.crci.2005.05.007.

13. M. Dhibi, B. Mechri, F. Brahmi, F. Skhiri, M.A. Alsaif and M. Hammami, J. Sci. Food Agric., 92, 1702 (2012); https://doi.org/10.1002/jsfa.5535.

14. M. Abi-Ayad, F.Z. Abi-Ayad, H.A. Lazzouni, S.A. Rebiahi, C. Cherif and J.M. Bessiere, J. Med. Plants Res., 5, 5433 (2011).

15. N. Boulaacheb, International Symposium on Medicinal and Aromatic Plants-SIPAM2009, p. 853 (2009);

https://doi.org/10.17660/ActaHortic.2010.853.53.

16. F. Macchioni, P.L. Cioni, G. Flamini, I. Morelli, S. Maccioni and M. Ansaldi, Flavour Fragrance J., 18, 139 (2003); https://doi.org/10.1002/ffj.1178.

17. A. Romani, F. Ieri, B. Turchetti, N. Mulinacci, F.F. Vincieri and P. Buzzini, J. Pharm. Biomed. Anal., 41, 415 (2006); https://doi.org/10.1016/j.jpba.2005.11.031. 
18. G. Blazso, M. Gabor, F. Schonlau and P. Rohdewald, Phytother. Res., 18, 579 (2004); https://doi.org/10.1002/ptr.1477.

19. O. Yesil-Celiktas, M. Ganzera, I. Akgun, C. Sevimli, K.S. Korkmaz and E. Bedir, J. Sci. Food Agric., 89, 1339 (2009); https://doi.org/10.1002/jsfa.3591.

20. S.T. Tukan, K. Al-Ismail, R.Y. Ajo and M.M. Al-Dabbas, Riv. Ital. Sostanze Grasse, 90, 87 (2013).

21. M. Sadeghi, B. Zolfaghari, A. Jahanian-Najafabadi and S.R. Abtahi, Res. Pharm. Sci., 11, 58 (2016).

22. Z. Djerrad, L. Kadik and A. Djouahri, Ind. Crops Prod., 74, 440 (2015); https://doi.org/10.1016/j.indcrop.2015.05.049.

23. N. Fekih, H. Allali, S. Merghache, F. Chaïb, D. Merghache, M. El Amine, N. Djabou, A. Muselli, B. Tabti and J. Costa, Asian Pac. J. Trop. Dis., 4, 97 (2014); https://doi.org/10.1016/S2222-1808(14)60323-6.

24. S. Maurya and D. Singh, Int. J. PharmTech. Res., 2, 2403 (2010).
25. J. Sun, Y.F. Chu, X. Wu and R.H. Liu, J. Agric. Food Chem., 50, 7449 (2002); https://doi.org/10.1021/jf0207530.

26. I. Trimech, E.K. Weiss, V.S. Chedea, D. Marin, A. Detsi, E. Ioannou, V. Roussis and P. Kefalas, Phytochem. Anal., 25, 421 (2014); https://doi.org/10.1002/pca.2510.

27. H. Salim, W.H. Rimawi and A. Mjahed, J. Chem. Biochem., 5, 12 (2017); https://doi.org/10.15640/jcb.v5n1a2

28. S. CheikhRouhou, B. Hentati, S. Bebes, C. Blecker, C. Deroanne and H. Attia, Food Sci. Technol. Int., 125, 407 (2006); https://doi.org/10.1177\%2F1082013206069910

29. H. Mahmoudi, K. Hosni, W. Zaouali, I. Amri, H. Zargouni, N.B. Hamida, R. Kaddour, L. Hamrouni, M.B. Nasri and Z. Ouerghi, J. Food Saf., 36, 77 (2016); https://doi.org/10.1111/jfs.12215.

30. M. Balouiri, M. Sadiki and S.K. Ibnsouda, J. Pharm. Anal., 6, 71 (2016); https://doi.org/10.1016/j.jpha.2015.11.005. 